\title{
The Influence of Living Values Education-Based Civic Education Textbook on Student's Character Formation
}

\author{
Kokom Komalasari \\ Prof., Faculty of Social Sciences Education, Indonesia University of Education, \\ Indonesia, komalasari110@yahoo.com
}

\section{Didin Saripudin}

Prof., Faculty of Social Sciences Education, Indonesia University of Education, Indonesia,kalimaya36@yahoo.co.id

This study aims to develop and examine a civic education textbook model based on living values education in order to foster the development of junior high school students' characters. This research employs Research and Development approach with an explorative method being used at model development stage and experiment method at model testing stage. Research subjects are teachers of Civics Education and junior high school students in Bandung, West Java, Indonesia. Data were gathered through observation, interview, focus group discussion, and attitude scale. Qualitative data analysis includes interactive analysis and quantitative data analysis uses a paired sample T-test. The results of the research are: 1) at a conceptual level, a living values education-based textbook is the integration of living values and the principles of living values education into textbooks by taking into account the principles of scientific learning, core competencies and basic competencies in accordance with the national curriculum, and the principles of textbook writing (content feasibility, presentation, language and readability, and graphics); and 2) the use of living values education-based Civic Education textbook significantly impacts the development of junior high school students' character.

Keywords: living values education, textbooks, civic education, character, students, junior high school, Indonesia

\section{INTRODUCTION}

The education policy in Indonesia situates Civic Education as one of the subjects focusing on the establishment of citizens who understand and are able to perform their rights and duties to become Indonesian citizens who are intelligent, skilled and mannered as mandated by Pancasila (the Five Principles) and the 1945 Constitution. Civic education is a compulsory subject at all levels of school education in Indonesia. The goals of Citizenship Education are as follows: 1) presents characters that reflect

Citation: Komalasari, K., \& Saripudin, D. (2018). The Influence of Living Values Education-Based Civic Education Textbook on Student's Character Formation. International Journal of Instruction, 11(1), 395-410. https://doi.org/10.12973/iji.2018.11127a 
awareness, understanding and practice of Pancasila personally and socially; 2) having a constitutional commitment supported by a positive attitude and a complete understanding of the 1945 Constitution of the State of the Republic of Indonesia; 3) Think critically, rationally, and creatively and have a spirit of nationalism and love of the country; 4) participate actively, intelligently and responsibly as members of society and citizens in accordance with their dignity as the creation of God Almighty living together in various social and cultural structures. (Regulation of Indonesia Minister of Education and Culture Number 58 year 2014 about Junior High School Curriculum 2013). Therefore, Civic Education carries the mission of enlightening Indonesians through nation and character building.

Bohlin et.al (2001) explains "The word "character" is taken from the Greek charassein, meaning "to mark" or "to inscribe upon." Over time the meaning has evolved into "a distinctive mark or sign," and from there grew our conception of character as "an individual's pattern of behaviour ... his moral constitution". It is a set of values that leads to a system, which underpins the thoughts, attitudes, and behaviors displayed. Character is related to character strength, which connotes 'positive' value, not neutral. Thereby, a person with character is a person who has a certain positive moral quality. 'Character strength' is directly related to virtues. Character strength is viewed as the psychological elements that cultivate virtues. One of the main criteria of 'character strength' is that the character contributes greatly to fully actualize one's potentials and ideals in building a good life, that is beneficial to oneself and to others (Philips, 2008; Peterson \& Seligman, 2004).

The character of the Indonesian nation is based on Pancasila as the foundation of the nation and the life vision of the Indonesian nation. This character is in line with the living values, i.e. a variety of habits universally underlying good and harmonious relationships between us and others around us. Personal and social values include peace, appreciation, love, responsibility, happiness, cooperation, honesty, humility, tolerance, modesty, freedom and unity (Tillman, 2004). The values of life are taught to learners through living values education program with various activities such as: (a) the point of reflection; (b) imagining; (c) relaxation/concentration exercises; (d) artistic expression; (e) self-development activities; (f) social skills; (g) the awareness of the value of social justice; (h) developing skills for social unity; (i) incorporating the values into the existing curriculum (Yunianto, 2009; Komalasari, 2012; Saripudin \& Komalasari, 2015).

The values of life and varying activities of living values education need to be integrated in civic education as the core activity in school, because civic education have the vision of nation character building. One of instrumental components of instructional input is textbook used as a learning source by students. A textbook is a learning handbook used in schools to present a large number of indirect experiences and to support the teaching program. It is a book about a particular field of study written with the purpose of facilitating the attainment of the learning process (Komalasari \& Saripudin, 2017). This book is designed for classroom use, carefully prepared and written by experts in the field, and equipped with appropriate and suitable learning tools (Wesley \& Wronski, 
1958). In general, textbooks serve as the main source used by the students in the teaching and learning process. They are deliberately prepared and written for students by people who master the subject with the aim of facilitating the process of teaching and/or learning (Sjamsuddin, 2004; Saripudin \& Komalasari, 2016a).

In actuality, character building has not yet been integrated into Civic Education textbooks. Based on the results of the Civic Education textbook analysis in schools, it was found that $80 \%$ textbooks contained knowledge material, and only $20 \%$ contained affective and psychomotor aspects (Somantri, 2001).This is because most textbooks of Civic Education in Indonesia emphasize on instructional effects that are limited to content mastery or only draw attention to cognitive dimensions. Meanwhile, the development of affective and psychomotor aspects and the acquisition of nurturant effects as "hidden curriculum" for the character development of the students still have not received ample attention (Komalasari \& Saripudin, 2017).

In general, textbooks of Civic Education in the market only teach students about the concepts and principles of the subject, but concern less on educating the students to behave and conduct oneself according to the concepts and principles of the subject in everyday life (Somantri, 2001). How to reconstruct Civic Education textbooks so that they can help shape the character of students? First, the Civic Education textbook has to be based on living values. It means that it is based on the basic values of life, thus it is easier to be internalized and implemented. Second, the Civic Education textbook should involve aspects of "knowing the good, desiring the good/loving the good and acting the good". Third, the textbooks are to be contextual, connecting the learning content with its practice in real life (Komalasari \& Sapriya, 2016).

All these characteristics are incorporated into the textbook model of Civic Education based on living values education as the conceptual material that takes into account the basic values of the students' life and makes the connection between one's moral knowledge and practices in the life of the student as a family member, a community member, and a citizen. This living values education based Civics Education textbook model is assumed to be able to effectively nurture the character of the students.

This study is to describe a model of living values education-based Civic Education Textbook and its impact on the character development of student. In particular, this study is to describe: 1) the conceptual model of living value education based-Civic Education textbook; 2) the framework of living value education based-Civic Education textbook model; and 3) the influence of the use of living value education based-Civic Education textbook model on the character development of the students.

\section{METHOD}

\section{Method}

This study is a rresearch and development design. It is "a process used to develop and to validate educational product" (Borg and Gall,1989). Development of a model of living values education-based Civic Education textbook is carried out through two forms of activity: (1) qualitative exploration to develop a living value education-based Civic 
Education textbook model, and (2) quantitative, through a quasi-experimental activity with pretest-posttest non-equivalent control group design to examine the influence of the textbook model toward the character development of junior high school students (Creswell: 2012).

\section{Process}

The research procedure "Research and Development" refers to Borg and Gall (1989) consisting of ten stages: (1) Research and information collecting, (2) Planning, (3) Develop preliminary form of product (living values education-based Civic Education textbook), (4) Preliminary field testing, (5) Main product revision, (6) Main field testing; (7) Operational product revision, (8) Operational field testing, (9) Final product revision; and (10) Dissemination and implementation living values education-based Civic Education textbook in schools through experiments to see the impact of using the book model on the character development of junior high school students

\section{Participants}

Participants in the introduction study were students of Junior High School (SMP), teachers of Citizenship Education as practitioners, and lecturers who are experts in materials and textbooks Citizenship Education. The participants of the experiment study were students of eighth grade in SMP 5 and SMP 7 Bandung Indonesia in the academic year of 2016/2017 as a pilot school for character education programs from the Ministry of Education and Culture. In each school is randomly assigned one experimental class and one control class. The total samples of the study were 160 students, consisting 40 students in each of the four groups studied. Experimental class was treated by living values education-based Civic Education textbook that developed by the researcher and control class was treated by conventional civic education textbook commonly used in schools (the book is published by government or private publishers that are materialoriented)

\section{Data Collection Tools}

Qualitative data were collected through (1) observation sheet, (2) documentation, and (3) interviews sheet. Quantitative data was collected through the attitude scale. Observations, interviews, focus group discussion and documentation were used to develop the living values education-based Civic Education textbook model, and the attitude scale was used to examine the influence of the textbook model on the character development of junior high school students. Atitude scale was tested for validity with Pearson's product-moment correlation and reliability tested with Cronbach's alpha (Shadish, et.al, 2002). Based on the test, instruments of attitude scale were valid with coefficient of correlation bigger than 0.404 ( $\mathrm{r}$ table) and have coefficient of alpha reliability $0.794>0.600$ indicates the instrument is reliable.

\section{Data analysis}

Analyzing qualitative data was carried out through several steps. The first is to hold data reduction by summarizing the field report, noting subject matters relevant to the focus of 
the study. The second is to develop a systematic way based on certain categories and classifications. The third isto make the display of data in the form of a table or a picture so that the relationship among the data with each other becomes clear and intact (not separated-off). The fourth is to conduct cross-site analysis by comparing and analyzing the data in depth. The fifth is to present the findings, to draw conclusions in the form of general trends, and to formulate the implications of its implementation, as well as recommendations for development (Fraenkel and Wallen, 2006). Analyzing quantitative data was performed for the data collected through attitude scale using different test analysis (gain score) by Wilcoxon's Matched Pairs Test and t- test by Mann-Whitney U Test (Shadish, et.al, 2002), because based on Kolmogorov-Smirnov normality test obtained Asymp. Sig. ( 2 tailed) $0,036<0,05$ indicates the data is not normally distributed. Quantitative data analysis was equipped with descriptive quantitative analysis using percentages (Creswell, 2012).

\section{FINDINGS}

\section{The conceptual model of living value education based-civic education textbooks}

The textbook under examination conceptually incorporates living values and the principles of living values education into the material of Civic Education according to core competencies and basic competencies and the principles of scientific learning couched under the 2013 curriculum by taking into account the principles of textbook writing (content feasibility, presentation, language and readability, and graphics) (Komalasari \& Saripudin, 2017).

The textbook model contains the material suited with the existing curriculum. The contents are presented fully, in-depth, accurately and up-to-date. The contents also foster a social-spiritual attitude, and develop knowledge and skills. The textbook distinguishes itself from other textbooks in that it digs and clarifies the values of life that are universal based on Pancasila as the Indonesian life vision, and preserves the values of local wisdom. The criteria of the contents of the living values education-based civic education textbook can be seen in the table 1 . 
Table 1

The content feasibility of the living values education-based civic education textbook model

\begin{tabular}{|c|c|}
\hline No. Assessed Aspects & Indicators \\
\hline $\begin{array}{l}\text { 1. Conformity of material description with } \\
\text { Core Competence and Basic } \\
\text { Competence in National Curriculum }\end{array}$ & $\begin{array}{l}\text { a. Comprehensiveness of the material } \\
\text { b. Depth of the material }\end{array}$ \\
\hline Accuracy of the material & $\begin{array}{l}\text { c. Accuracy of the facts } \\
\text { d. Validity and accuracy of the concept } \\
\text { e. Validity and accuracy of the theory } \\
\text { f. Accuracy of the method }\end{array}$ \\
\hline 3. Recency & $\begin{array}{l}\text { g. Conformity of the material with the } \\
\text { advancement of the science } \\
\text { h. Interesting, relevant, and current features and } \\
\text { examples } \\
\text { i. Recent and appropriateness of the reference }\end{array}$ \\
\hline 4. Cultivating a spiritual attitude & $\begin{array}{l}\text { Encouraging the students' gratitude towards the } \\
\text { Almighty God }\end{array}$ \\
\hline 5. Developing the living values & $\begin{array}{l}\text { Fostering the development of character values: } \\
\text { peace, appreciation, love, responsibility, } \\
\text { happiness, cooperation, honesty, humility, } \\
\text { tolerance, modesty, freedom, and unity. }\end{array}$ \\
\hline 6. Developing the skills & $\begin{array}{l}\text { Developing the materials that encourage students } \\
\text { to be skillful }\end{array}$ \\
\hline 7. Developing the knowledge insight & $\begin{array}{l}\text { Developing the conceptual and procedural } \\
\text { capabilities in areas of study suitable with their } \\
\text { interests. }\end{array}$ \\
\hline
\end{tabular}

The textbook should have a distinctive feature on its presentation (self-reflection, value exploration, creative expression, personal-social-emotional skills, life value implementation, and attitude assessment). Besides, it should meet the requirements for the presentation of the book that is systematic, coherent, and consistent, and meets the demands of presentation based on the 2013 curriculum that underscores the scientific learning approach. The criteria of presentation of living values education-based Civic Education textbook can be seen in the table 2 . 
Table 2

The feasibility of presentation of the living values education-based civic education textbook

\begin{tabular}{|c|c|c|}
\hline No. & Assessed Aspects & Indicators \\
\hline 1. & Techniques of presentation & $\begin{array}{ll}\text { a. } & \text { Arrangement } \\
\text { b. Coherence } \\
\text { c. Consistency of presentation techniques } \\
\text { with terms and symbols/attributes } \\
\text { d. Compatibility and appropriateness of the } \\
\text { illustrations with the material in the } \\
\text { chapter }\end{array}$ \\
\hline 2 & $\begin{array}{l}\text { Presentation of Scientific Learning } \\
\text { ( } 2013 \text { Curriculum) }\end{array}$ & $\begin{array}{l}\text { a. Centered on learners' learning activities } \\
\text { with a scientific approach suitable with the } \\
\text { national curriculum } \\
\text { b. Stimulating learners' ability in the } \\
\text { observation and interview, categorizing the } \\
\text { information, analyzing and synthesizing, } \\
\text { constructing and communicating a certain } \\
\text { topic } \\
\text { The presentation of the material employs } \\
\text { these models: project learning, problem- } \\
\text { solving learning, and discovery learning } \\
\text { d. Developing performance's assessment, } \\
\text { project's assessment portfolio, attitude } \\
\text { assessment, and written test }\end{array}$ \\
\hline 3. & $\begin{array}{l}\text { Presentation of Learning (Living } \\
\text { Values Education) }\end{array}$ & $\begin{array}{ll}\text { a. Developing self-reflection skills } \\
\text { b. Developing explorative skill of real life } \\
\text { c. } \\
\text { values } \\
\text { d. Developing personal, social, and } \\
\text { emotional skill } \\
\text { e. Developing the capability to implement } \\
\text { the values of life }\end{array}$ \\
\hline
\end{tabular}

The textbook has to meet the aspects of language and readability, and graphics. The language and readability aspects are crucial to make a book fit with the students' abilities and needs, easy to understand, motivatee, encourage critical-creative-innovative thinking, and clarify and implement student life values. Graphic aspects that include the form, layout, image proportionality, and clarity of illustrations can amplify the development of student motivation to read, understand the content, clarify and implement the value of characters obtained in daily life.

The Framework of Living Values Education based-Civic Education Textbook

Based on the conceptual model above, then a Civic Education textbook is written within a framework/outline as follows:

1. Book Identity consists of: a) Cover, containing titles of books and authors' name; b) Foreword, giving the reader a general idea of the content of the book or an initial 
overview of the book; c) How to Use Books, providing a brief guide on how to read the book, so that it can give an optimal understanding of facts, data, principles, procedures, values-morals-norms, and reflection skills; and d) Table of Contents

2. Book Content consists of:

a. The title of chapter/discussion, reflecting the material and the value of life to be developed;

b. Introduction, starting with pictures, stories, poems, cases, etc., followed by the apperception of material and reflection of life values that will be developed;

c. Map of concept and keywords, presenting a general description of the material and the values of life to be developed in the chapter/discussion;

d. Presentation of the material and clarification of the living values, including facts, concepts, principles, procedures, and living values (behavior and attitudes). The living values in the textbook are presented in the features of civic values and wise words.

e. Performance/demonstration of competence; students are invited to conduct a series of civic practices in developing citizenship competencies (knowledge, attitude/values/character, thinking skills, and participatory skills). The values of life are integrated in the performance of competence/assignment through analyzing the value of life in value-laden stories, songs, and poetries,

f. Summary, containing the conclusions of learning materials that must be mastered and the values of life that must be developed.

g. Reflection/afterthought, containing reflections on the values of life practiced in everyday life through Value Clarification Technique (VCT) List. This reflection and afterthought can be presented as an instrument to assess students' attitudes and behaviors.

h. Authentic assessment, consisting of a set of instrument for student assessment (tests, attitude scale, and performance)

i. Feedback, containing answer keys and assessment form with the assessment rubric.

j. Follow-up activities (transfer, enrichment, remedial), containing the direction of further activities for material enrichment for those who have achieved the expected competence and remedial for those who have not attained the expected competence (Komalasari and Saripudin, 2017).

2. Book Closing includes: a) Glossary, a list of concepts that often appear in text and requires explanation; 2) Bibliography, a collection of sources referred to in the discussion/description of the material in the entire chapter of the textbook; and c) Index, a list of important words or terms arranged alphabetically that provide information about the page where the word or term is found.

\section{The Influence of the Living Value Eeducation based-Civic Education Textbooks on Student's Character}

Based on the test results of paired samples t-test, Sig. (2-tailed) is $0.000<\mathrm{a}(0.05)$. It means there is a difference in the development of students' civic disposition at the beginning of the measurement (pretest) from the final measurement (posttest) in both the 
experimental and control classes. The mean value of pretest and posttest in the experimental class are better than the pretest and posttest in the control class.

The gained scored control and experiment classes show significant differences in the development of students' character formation between the class that uses living values education-based Civic Education textbook (SMP A = 1.12 and SMP B = 1.04) with the class that uses conventional Civic Education textbook (SMP A $=0.40$ and SMP B = 0.30). Students' character formation in the class that integrates living values in the Civic Education textbook is higher than the other one that uses conventional Civic Education textbook. The average score of pretest-posttest and gained score control and experiment classes can be seen in the table 3 .

Table 3

Average score of pretest - posttest and gained score control and experiment classes

\begin{tabular}{|c|c|c|c|c|c|c|c|}
\hline School & Classroom Data & Mean & $\begin{array}{l}\text { Standard of } \\
\text { Deviation }\end{array}$ & Variants & Gain & $\begin{array}{l}\mathrm{N} \\
\text { Gain }\end{array}$ & $\begin{array}{l}\text { Asymp } \\
\text { Sig } \\
\end{array}$ \\
\hline \multirow{4}{*}{$\begin{array}{l}\text { Junior } \\
\text { High } \\
\text { School A }\end{array}$} & Control Pre-test & 49,44 & 7,037 & 49,516 & 2,06 & 0,40 & \multirow{4}{*}{0.000} \\
\hline & Control Post-test & 70,10 & 7,500 & 56,252 & & & \\
\hline & Experiment Pre-test & 49,31 & 9,855 & 97,113 & \multirow[b]{2}{*}{5,69} & \multirow[b]{2}{*}{1,12} & \\
\hline & Experiment Post-test & 106,28 & 8,693 & 75,576 & & & \\
\hline \multirow{4}{*}{$\begin{array}{l}\text { Junior } \\
\text { High } \\
\text { School B }\end{array}$} & Control Pre-test & 56,65 & 5,641 & 31,823 & 1,32 & 0,30 & \multirow{4}{*}{0.000} \\
\hline & Control Post-test & 69,93 & 4,752 & 22,584 & & & \\
\hline & Experiment Pre-test & 57,27 & 5,511 & 30,369 & \multirow[b]{2}{*}{4,48} & \multirow[b]{2}{*}{1,04} & \\
\hline & Experiment Post-test & 102,11 & 8,144 & 66,321 & & & \\
\hline
\end{tabular}

The results of descriptive quantitative data analysis, the character of the students developed through the use of living values education-based Civic Education textbooks model in the experimental class can be seen in Table 4. 
Table 4

The development of student's character in experiment class

\begin{tabular}{|c|c|c|c|c|c|}
\hline \multirow{2}{*}{$\begin{array}{l}\text { Name of Junior } \\
\text { High School }\end{array}$} & \multirow{2}{*}{$\begin{array}{l}\text { Aspects assessed of } \\
\text { Living Values }\end{array}$} & \multicolumn{4}{|c|}{ Assessment Results $(\mathrm{N}=80)$} \\
\hline & & $\begin{array}{c}\text { Very } \\
\text { Good } \\
(\%)\end{array}$ & $\begin{array}{c}\text { Good } \\
(\%)\end{array}$ & $\begin{array}{r}\text { Poor } \\
(\%)\end{array}$ & $\begin{array}{c}\text { Very } \\
\text { Poor } \\
(\%)\end{array}$ \\
\hline \multirow[t]{13}{*}{ Junior High School A } & Peace & 71 & 10 & 10 & 9 \\
\hline & Respect & 64 & 18 & 14 & 2 \\
\hline & Love & 65 & 19 & 12 & 6 \\
\hline & Tolerance & 80 & 11 & 7 & 2 \\
\hline & Honesty & 60 & 27 & 10 & 3 \\
\hline & Humility & 65 & 16 & 10 & 7 \\
\hline & Cooperation & 82 & 10 & 6 & 2 \\
\hline & Happiness & 72 & 15 & 12 & 1 \\
\hline & Responsibilities & 61 & 20 & 12 & 7 \\
\hline & Simplicity & 65 & 15 & 14 & 6 \\
\hline & Freedom & 62 & 25 & 11 & 2 \\
\hline & Unity & 80 & 10 & 8 & 2 \\
\hline & & 68,9 & 16.3 & 10.5 & 4.3 \\
\hline \multirow[t]{13}{*}{ Junior High School B } & Peace & 70 & 15 & 10 & 5 \\
\hline & Respect & 70 & 19 & 8 & 3 \\
\hline & Love & 65 & 20 & 8 & 4 \\
\hline & Tolerance & 82 & 10 & 6 & 2 \\
\hline & Honesty & 65 & 28 & 5 & 2 \\
\hline & Humility & 65 & 20 & 9 & 6 \\
\hline & Cooperation & 85 & 7 & 5 & 3 \\
\hline & Happiness & 76 & 13 & 8 & 3 \\
\hline & Responsibilities & 62 & 20 & 10 & 8 \\
\hline & Simplicity & 68 & 19 & 8 & 5 \\
\hline & Freedom & 60 & 20 & 12 & 8 \\
\hline & Unity & 85 & 10 & 4 & 1 \\
\hline & & 71.2 & 16.8 & 7.8 & 4.2 \\
\hline Total & & 71.1 & 16.6 & 9.1 & 4.2 \\
\hline
\end{tabular}

Table 4 above shows that the character score of the students after the use of living values education-based civic education textbook in junior high school sits at $71.1 \%$ (very good category), $16.6 \%$ (good category), $9.1 \%$ (poor category), and only $4.2 \%$ (very poor category). The dominant student character developed by the living values education-based civic education textbook is cooperation, unity, and tolerance, and which is still lacking and should be more developed is responsibility, freedom, and honesty. 


\section{DISCUSSION}

The use of living values education-based Civic Education textbook significantly impacts the development of junior high school students' character. The results of this study can be explained as follows. First, living values education-based textbook is the main source of learning for students, so that the values of life and their application can be learned by the students through the book. This suggests conformity with the opinion of Chambliss $\&$ Calfee (1998) who make it clear that textbooks are a tool for learners to understand and learn from what they read. A textbook is also a tool for understanding the world. The power of textbooks affects students' knowledge and values. More generally, textbooks appear to be a central part of the educational system, the medium of curriculum material conveyers including attitudes and behaviors, thus holding a dominant role in the classroom (Buckingham, 1960; Patrick, 1998; Lockeed \& Verspoor, 1990; Altbach et al, 1991). Therefore, textbooks must be of high quality that is meeting the standards of content feasibility, presentation, language and legibility, and graphics. Content wise, a textbook should contain comprehensive material covering facts, concepts, principles, procedures, and values of life, and in terms of presentation, it should incorporate scientific learning and the principles of living values education (Saripudin \& Komalasari, 2016a; Komalasari \& Saripudin, 2017).

Second, living value education based-textbook contains material in form of character values derived from the nation's life vision, not only material in form of facts, concepts, principles and procedures oriented to the mastery of certain disciplines. The textbook is essentially a compulsory reference book for use in schools containing instructional materials intended to improve faith and piety, character and personality, the ability of science and technology mastery, sensitivity and aesthetic ability, physical and health potential, which is written based on national standards of education. Therefore, textbooks should contain teaching materials taken from the discipline of science and the environment, in accordance with the valid curriculum, practical values of life according to the needs of students, and learning experiences for learners that are organized in a balanced, functional, structural, humanistic, and civic approach (Hanna \& Lee, 1962; Komalasari et al, 2014; Komalasari \& Sapriya, 2016; Somantri, 2001)

Third, in living value education based-textbooks, life values or characters are taught through a variety of interesting activities, such as stories, songs, poems, rhymes, civic value features, wise words from national and world figures, reflection and attitude assessment at the end of the material presentation (Komalasari \& Saripudin, 2017). Thus, in addition to that the contents must be scientific, logical, systematic, developmentally appropriate, using a spiral approach, and include informative and attractive illustrations (Sjamsuddin, 2004), the presentation aspect of living value basedtextbooks become important in order that the message of character values or living values can be internalized by students as the readers. Textbook writing should pay attention to the learning strategy components and design of subject matter (Gafur, 1986; Komalasari, 2010). The presentation of information in a textbook can fulfill as many as possible aspects of the learning activities which the students can do independently, so that there is a relatively permanent change in the skills, attitudes and behaviors of 
students as a result of the learning experience from the textbooks as the source of learning.

Fourth, the living value education based-Civic Education textbook provides an indirect experience to learners about meaningful life values for their lives. Students build new experiences based on their initial experience with the book. This principle shows that the most authentic source of learning is experience. According to Covey (2006), learning is an attempt to inspire ourselves and others. The way to do it is to know yourself and listen to your conscience. Self-knowledge and the inclusion of conscience imply the high value of experience. Rich in experiences can be obtained in various ways, i.e. reading, especially reading textbooks. The more a person reads, the higher her/his reading skill will be. By reading a book, one can gain a great deal of indirect experiences. Indeed, in education it is a valuable thing if learners can experience something directly. However, many parts of the lessons cannot be obtained by direct experiences. Therefore, by studying at school, and also learning from life outside the school, acquiring indirect experiences is very important (Suryaman \& Utorodewo, 2006). The advancement of civilization nowadays has received much support from reading activities. Textbooks as media and source of learning play a role in bringing the learners closer to the reality of life brought into the classroom through textbooks. Students will learn well if what they learn is related to what they already know (Dewey, 1966). Therefore, textbooks should be contextual and rich with practical examples of materials and life values for students as a meaningful indirect experience for their lives.

Fifth, research results support previous research that textbooks play a meaningful role in student achievement, including affective learning results that lead to the acquisition of attitudes and behavior. In the World Bank Report (1995) on Indonesia, it is reported that the level of student ownership of books and other facilities correlates with student achievement. This statement is supported by Supriadi (2000) who states that the level of student ownership of the book is positively correlated with and meaningful to the learning achievement. The learning outcomes of civic education are the achievement of civic competences as civic education goals that include civic knowledge, civic skills, and civic dispositions (Center for Civic Education, 1994; Branson, 1999). Character development is closely connected to civic disposition, which is "...those attitudes and habit of mind of the citizen that are conducive to the healthy functioning and common good of the democratic system". Conceptually, civic disposition consists of a number of personality characteristics, namely: "Civility (respect and civil discourse), individual responsibility, self-discipline, civic-mindedness, open-mindedness (openness, skepticism, recognition of ambiguity), compromise (conflict of principles, compassion, generosity, and loyalty to the nation and its principles" (Quigley et al, 1991).

Sixth, the use of living value education based-textbook model is more dominant in developing the character of unity, cooperation, and tolerance of the students, and is still considered less in developing the character of freedom, honesty and responsibility of the students. Hypocritical mentality (dishonesty) and irresponsibility are the cultural mentality of the Indonesian nation which is the remaining of feudalism mentality that must be eroded out, because it is not in accordance with the nation's development 
mentality. The development of socio-cultural values, such as honesty and responsibility, can be developed in schools through culture-based learning (Kontjaraningrat, 2000; Saripudin \& Komalasari, 2016b). Likewise, the honesty and responsibility character become the top priority of Anti-Corruption Education. It is implemented at schools through various activities, that is: it is integrated in the curriculum of civic education, both in the material and learning process, the use of anti-corruption education module, nurturing anti-corruption behavior through Honest Canteen, and creating anti-corruption atmospheres in school through the school rules and code of conduct (Komalasari \& Saripudin, 2015).

Seventh, in addition to the teacher's role as a facilitator for the use of textbooks by students when learning in the classroom, the author of the book also occupies an important position in producing quality textbooks. Quality textbooks can present information which readers can readily understand. The author guarantees written communication with the reader by presenting connected and systematic information in his book. In order that textbooks have a high benefit, the author also presents sharp and reachable information that can be learned through his book. Good books contain vision (direction), mission (message), context (relevance), content, and a process of presented information (Martono, 2005). A writer must have the credibility and competence in the field of material and in presenting the material in an engaging way, so the students are the eager to learn from the book. That is wht textbook writing should be done the fullest (Rusyana \& Suryaman, 2004).

\section{CONCLUSION}

The proposed textbook model is an integration of living values and the principles of living values education into civic education textbooks by taking into account the principles of scientific-contextual learning, developing core ccompetencies and bbasic ccompetencies' in accordance with the existing curriculum, the principles of the writing of textbook material, presentation, language and readability, and graphics. The book is an innovation in providing quality learning resources, especially in developing the character of the students. It includes Book Identity (cover, introduction, how to use the book, and table of contents), Book Contents (chapter title, introduction, concept map and keywords, presentation of material and clarification of life values, stimulating performance/demonstration of living value based-competencies, summary, reflection, authentic assessment, feedback, and follow-up activities), and book closing (glossary, index, bibliography). This textbook has a significant and positive influence on the development of student characters. The student characters that are dominantly developed through this book are cooperation, unity, and tolerance. Therefore, this book is expected to be used by students and teachers as a source of learning Civic Education in junior high school in Indonesia as an effort to strengthen character education through integration in learning.

\section{Acknowledgments}

The research is a grant from the Ministry of Research, Technology, and Higher Education of Indonesia through the Competence Research Program. The author would like to express sincere appreciation for all support provided. 


\section{REFERENCES}

Altbach, P. G., Kelly G. P., \& Petrie, H. G. (1991). Textbooks in American Society: Politics, Policy, and Pedagogy. Buffalo: SUNY Press.

Bohlin, K. E., Farmer, D., Ryan, K. (2001). Building Character in School Resource Guide.San Fransisco: Jossey Bass.

Borg, W. R., \& Gall, M. D. (1989). Educational research: An introduction (5 ${ }^{\text {th }}$ ed). New York: Longman.

Branson, M. S. (1999). Making the case for civic education: Where we stand at the end of the $20^{\text {th }}$ century. Washington: Center for Civic Education.

Buckingham, B. R. (1960). "Textbooks", in Encyclopedi of Educational Research, Third Edition, (Ed.) Chester W. Harris, (ass.) Marrie R. Liba. New York: The MacMillan Company.

Center for Civic Education/CCE. (1994). Civitas: National standards for civics and government. Calabasas: Center for Civic Education.

Chambliss, M. J. dan, \& R.C. Calfee (1998), Textbooks for learning: Nurturing children's minds, massachusetts: Blackwell Publishers.

Covey, S. R. (2006). The 7th habit: from effective to greatness. New York: Free. Press.

Creswell, J. W. (2012). Educational research: Planning, conducting, and evaluating quantitative and qualitative research. Boston: Pearson Education, Inc.

Dewey. J. (1966). Democracy and education: An introduction to the philosophy of education. New York: Free Press.

Fraenkel, J.R., \& Wallen, N.E. (2006). How to design and evaluate in research. New York: The McGraw-Hill Companies, Inc.

Gafur, A. (1986). Desain instructional: Suatu langkah sistematis penyusunan pola dasar kegiatan belajar mengajar. [Instructional design: A systematic steps in preparation of basic pattern of teaching and learning activities]. Solo: Tiga Serangkai.

Hanna, P., \& Lee, J. (1962). "Content in the social studies". In Michaelis, J.U. (ed). (1962). Social Studies in Elemenary Schools, $32^{\text {nd }}$ Yearbook. Washington D.C.: NCSS.

Koentjaraningrat (2000). Kebudayaan, mentalitas dan pembangunan [Culture, Mentality and Development]. Jakarta: Gramedia Pustaka Utama, ISBN. 9796860058, 9789796860050 .

Komalasari, K. (2010). Pembelajaran kontekstual: Konsep dan aplikasi. [Contextual teaching and learning: Concept and application]. Bandung: Refika Aditama.

Komalasari, K. (2012). The living values-based contextual learning to develop the students' character. Journal of Social Science, 8(2), 246-257. DOI: $10.3844 / \mathrm{jssp} / 2012.246 .251$. 
Komalasari, K., Saripudin, D., \& Masyitoh, I. M. (2014). Living values education model in learning and extracurricular activities to construct the students' character. Journal of Education and Practice, 5(7), 166-174.

Komalasari, K., \& Saripudin, D. (2015). Integration of anti-corruption education in school's activities. American Journal of Applied Sciences, 12(6), 445-451. DOI: 10.3844/ajassp2015.445.451.

Komalasari, K., \& Sapriya (2016). Living values education in teaching materials to develop students' civic disposition, The New Educational Review, 44(2), 107-124. DOI: 10.15804/tner.2016.44. 2.09.

Komalasari, K., \& Saripudin, D. (2017). A model of living values education-based civic education textbooks in Indonesia. The New Educational Review, 47(1), 139-150. DOI: 10.15804/tner. 2017.47.1.11.

Locked, M., \& A. Verspoor. (1990). Improving primary education in developing countries: A review of policy options. Washington DC: World Bank.

Martono, K. (2005). Peranan buku dalam proses belajar mengajar . [The role of books in teaching and learning]. Retrieved 1 December, 2013 from www.ganeca. blogspirit.com.

Patrick, J. J. (1998). High school government textbooks. Eric Digest, Ed 301532, December.

Peterson, C., \& Seligman, M. E. P. (2004). Character strengths and virtues a handbook and classification. Washington, D. C.: APA Press and Oxford University Press.

Philips, S. (2008). Refleksi karakter bangsa [Reflection on nation character]. Jakarta: Gramedia.

Quigley, C. N., Buchanan, Jr. J. H., \& Bah,ueller, C. F. (1991). Civitas: A framework for civic education. Calabasas: Center for Civic Education.

Regulation of Indonesia Minister of Education and Culture Number 58 year 2014 about Junior High School Curriculum 2013.

Rusyana, Y. dan, \& M. Suryaman. (2004). Pedoman penulisan buku pelajaran bahasa dan sastra Indonesia [Guidelines for writing indonesian language and literature books]. Jakarta: Pusat Perbukuan Departemen Pendidikan Nasional.

Saripudin, D., \& Komalasari, K., (2015). Living values education in school's habituation program and its effect on student's character development. The New Educational Review, 39(1), 51-62.

Saripudin, D., \& Komalasari, K. (2016a). The development of multiculturalism values in indonesian history textbook. American Journal of Applied Sciences, 13(6), 827-835. DOI: 10.3844/ajassp.2016.827.835. 
Saripudin, D., \& Komalasari, K. (2016b). Culture-based contextual social studies learning for development of social and cultural values of junior high school students. The Social Sciences, 11(23), 5726-5731. DOI: 10.3923/sscience. 2016. 5726.5731.

Shadish, W. R., Cook, T. D., \& Campbell, D. T. (2002). Experimental and quasiexperimental design for generalized causal inference. Boston: Houghton Mifflin Company.

Sjamsuddin, H. (2004). Penulisan buku teks sejarah: Kriteria dan permasalahannya [Historical Textbook Writing: Criteria and Problem] Historia, 1(1), 1-12.

Somantri, N. (2001). Menggagas pembaharuan pendidikan IPS. [Promoting social studies reform]. Bandung: Remadja Rosdakarya

Supriadi (2000). Anatomi buku sekolah di Indonesia: Problematik penilaian, penyebaran dan penggunaan buku pelajaran, buku bacaan dan buku sumber [Anatomy of school books in Indonesia: Problematic assessment, distribution and use of textbooks, books and sources books]. Jakarta: Adi Cita.

Suryaman, M., \& Utorodewo, V. N. (2006). Pemilihan dan pemanfaatan buku pelajaran yang memenuhi syarat kelayakan [Selection and utilization of a textbook that meets the eligibility requirements]. Jakarta: Pusat Perbukuan Departemen Pendidikan Nasional.

Tillman, D. (2004). Living values: Avtivities for children ages 8-14. Jakarta: PT Gramedia Widiasarana Indonesia.

Wesley, E. B., \& Wronski, S. P. (1958). Teaching social studies in high school. Boston: D. C. Health.

World Bank. (1995). Re-engeneering education for change. education innovation for development. Bangkok: Acied.

Yunianto (2009). Living values: An educational program educator training guide. Retrieved 9 February, 2014 from http://heruyunianto.blogspot.com/2009/05/livingvalues-educational program_26.html. 